STUDIA PRAWNO-EKONOMICZNE, t. CIV, 2017

PL ISSN 0081-6841; e-ISSN 2450-8179

s. $45-62$

DOI: $10.26485 / \mathrm{SPE} / 2017 / 104 / 3$

\title{
Iga JAWORSKA*
}

\section{STOSOWANIE PRZYMUSU BEZPOŚREDNIEGO W POSTĘPOWANIU EGZEKUCYJNYM W ADMINISTRACJI}

\section{(Streszczenie)}

Przymus bezpośredni jest jednym ze środków egzekucyjnych dotyczących egzekucji obowiązków o charakterze niepieniężnym, stosowanych przez organ egzekucyjny w administracyjnym postępowaniu egzekucyjnym. Niewątpliwe jest to środek najbardziej uciążliwy dla zobowiązanego, bowiem może ingerować w jego nietykalność. $Z$ drugiej strony jest to środek zazwyczaj prowadzący bezpośrednio do wykonania obowiązku przez zobowiązanego, a tym samym skuteczny. Celem artykułu jest zbadanie charakteru prawnego, wskazanie przesłanek oraz trybu stosowania tego środka egzekucyjnego oraz trudności, jakie może napotkać organ egzekucyjny, dążąc do jego zastosowania.

Słowa kluczowe: przymus bezpośredni; środki egzekucyjne; postępowanie egzekucyjne; egzekutor; obowiązek

\section{Wstęp}

Działania administracji publicznej polegające na egzekwowaniu obowiązków są zawsze skierowane do konkretnego adresata, za pomocą konkretnego środka egzekucyjnego. Przymus bezpośredni jest jednym z nich. Jako środek najbardziej uciążliwy dla zobowiązanego powinien być stosowany z wielką rozwagą organu egzekucyjnego i egzekutora. Postępowanie egzekucyjne w administracji, pomimo fundamentalnego znaczenia w zakresie zapewniania wykonania obowiązków przez ich adresatów, tym samym realizacji zasady państwa prawnego, nie jest przedmio-

* Mgr, doktorant, Wydział Prawa Administracji i Ekonomii Uniwersytetu Wrocławskiego, Zakład Postępowania Administracyjnego i Sądownictwa Administracyjnego, inspektor wojewódzki ds. kontroli i egzekucji w Wydziale Nadzoru i Kontroli Dolnośląskiego Urzędu Wojewódzkiego we Wrocławiu; e-mail: iga.jaworska@uwr.edu.pl 
tem wystarczająco wnikliwej debaty naukowej. Instytucja środka egzekucyjnego, jakim jest przymus bezpośredni, jest pomijana w opracowaniach przedmiotu.

Celem artykułu jest zbadanie charakteru prawnego oraz szczegółowe omówienie procedury stosowania przymusu bezpośredniego z uwzględnieniem jej skuteczności. Podjęta zostanie także próba odpowiedzi na pytanie, czy przesłanki zastosowania omawianego środka egzekucyjnego zostały ustanowione w sposób uwzględniający ochronę zobowiązanego. $Z$ uwagi na liczne wątpliwości zarówno prawne, jak i wynikające z praktyki prowadzonych postępowań egzekucyjnych, takie jak m.in. konsekwencje odmowy udzielenia pomocy przez organy asystujące i pomocnicze przy wykonywaniu czynności egzekucyjnych, problem konieczności zastosowania przymusu bezpośredniego jako pierwszego środka w postępowaniu w zakresie realizacji zasady celowości, a zarzut dotyczący zastosowania zbyt uciążliwego środka egzekucyjnego czy możliwość stosowania przymusu bezpośredniego przez egzekutora, podjęta zostanie próba ich wnikliwszej analizy.

\section{Pojęcie i przesłanki stosowania przymusu bezpośredniego}

Przymus bezpośredni jest jednym ze środków egzekucyjnych stosowanych w przypadku egzekucji obowiązków o charakterze niepieniężnym. Zgodnie $\mathrm{z}$ art. $148 \S 1$ ustawy z dnia 17 czerwca 1966 r. o postępowaniu egzekucyjnym $\mathrm{w}$ administracji ${ }^{1}$ przymus bezpośredni polega na doprowadzeniu do wykonania obowiązku podlegającego egzekucji drogą zagrożenia zastosowania lub drogą zastosowania bezpośrednio skutecznych środków, nie wyłączając siły fizycznej, w celu usunięcia oporu zobowiązanego i oporu innych osób, które stoją na przeszkodzie wykonaniu obowiązku. Należy podkreślić, że ustawodawca nie wskazuje, co należy rozumieć pod pojęciem „,bezpośrednio skuteczne środki”, jest to więc pojęcie pozostawione interpretacji organu egzekucyjnego. $\mathrm{Z}$ uwagi na różnorodność obowiązków niepieniężnych oraz sytuacji, w jakich znajdują się zobowiązani, nie sposób stworzyć katalogu sposobów realizacji tego środka egzekucyjnego, bowiem każdy stan faktyczny będzie mógł nieco modyfikować sposoby jego zastosowania. Będą istniały również sytuacje, $w$ których stosowanie przymusu będzie wymagało zastosowania kilku różnych form (np. obezwładnienie i doprowadzenie w konkretne miejsce). W zależności od sytuacji środek ten będzie przybierał różne formy. Dla przykładu w przypadku wykonania obowiązku stawienia się na

\footnotetext{
Dz.U. z 2016 r., poz. 599 z późn. zm.
} 
kwalifikację wojskową przymus będzie realizowany poprzez doprowadzenie zobowiązanego na miejsce kwalifikacji, natomiast w przypadku oporu przy wydaniu nieruchomości będzie polegał np. na usunięciu zobowiązanego z egzekwowanej nieruchomości. Za Joanną Radwanowicz można podać, że stosowanie przymusu może polegać zarówno na oddziaływaniu na osobę, jak również na oddziaływaniu na rzecz (np. w przypadku zastosowania kolczatki drogowej) ${ }^{2}$. Ponadto oddziaływanie to może przybrać formę zagrożenia lub zastosowania określonych środków materialnych (np. pałki) bądź określonego zachowania (np. przytrzymywaniu, wyprowadzeniu z pomieszczenia, chwytów obezwładniających). Na marginesie warto zaznaczyć, że w prawie niemieckim w ramach przymusu bezpośredniego zawarte sa jeszcze dwa środki egzekucyjne: odebranie rzeczy ruchomej i odebranie nieruchomości, opróżnienie lokalu i innych pomieszczeń3 ${ }^{3}$ Środki te określa się jako szczególne przypadki przymusu bezpośredniego ${ }^{4}$.

Należy wskazać, że z uwagi na represyjny charakter tej instytucji prawnej środek ten powinno stosować się w ostateczności, gdy nie ma możliwości użycia innych środków lub gdy inne środki są nieskuteczne. Mogą bowiem wystapić takie postępowania egzekucyjne, w których stosowanie grzywny w celu przymuszenia będzie niezgodne z zasadą celowości, np. gdy zobowiązanym będzie bardzo zamożna osoba fizyczna, a obowiązek będzie polegał na jej osobistym działaniu. Wówczas jedynym środkiem pozostającym w dyspozycji organu egzekucyjnego może pozostać przymus bezpośredni. Podobna sytuacja będzie miała miejsce, gdy po zastosowaniu maksymalnych stawek grzywny w celu przymuszenia ${ }^{5}$, środek ten okaże się nieskuteczny.

Wymaga zaznaczenia, że ustawodawca w art. $148 \S 2$ ustawy egzekucyjnej uregulował katalog przykładowych sytuacji, w których przymus można zastosować, stanowiąc, że przymus bezpośredni w szczególności stosuje się w celu doprowadzenia do wykonania przez zobowiązanego opuszczenia nieruchomości, lokalu (pomieszczenia), wydania rzeczy, zaniechania czynności lub nieprzeszkadzania innej osobie w wykonywaniu jej praw, a także w przypadkach, gdy ze

2 J. Radwanowicz, Przymus bezpośredni w egzekucji administracyjnej, w: J. Niczyporuk, S. Fundowicz, J. Radwanowicz (red.), System egzekucji administracyjnej, C.H. Beck, Warszawa 2004, s. 488.

3 Szerzej na temat przymusu bezpośredniego w prawie niemieckim zob. P. Ostojski, Zastosowanie przymusu bezpośredniego w egzekucji administracyjnej obowiązków niepieniężnych w Polsce i Niemczech, Państwo i Prawo 2013/8, s. 69 i n.

4 M. App, A. Wettlaufer, Praxishandbuch. Verwaltungsvollstreckungsrecht, Köln 2011, s. 190, nb. 1.

5 Art. 121 i n. ustawy o postępowaniu egzekucyjnym w administracji. 
względu na charakter obowiązku stosowanie innych środków egzekucyjnych nie jest możliwe. Należy podkreślić, że wyliczenie zawarte w powyższym przepisie nie stanowi katalogu zamkniętego, a jedynie przykłady użycia tego środka egzekucyjnego. Dopiero przepisy szczególne dotyczące działalności podmiotów, które de facto stosują przymus bezpośredni, będą określać konkretne środki przymusu bezpośredniego, możliwe do zastosowania w konkretnej sytuacji.

Niewątpliwie podstawowym aktem regulującym rodzaje środków przymusu będzie ustawa o środkach przymusu bezpośredniego i broni palnej ${ }^{6}$, która zawiera katalog tych środków, przesłanki ich stosowania oraz uprawnione organy. Wobec powyższego jednoznacznie należy podkreślić, że egzekutor, jeżeli nie jest pracownikiem organu uprawnionego do stosowania przymusu bezpośredniego na podstawie ustawy, nie jest uprawniony do osobistego stosowania przymusu bezpośredniego, a jedynie do zagrożenia jego użycia oraz wezwania organu udzielającego pomocy do zastosowania przymusu. Dobór odpowiedniej formy będzie pozostawiony decyzji funkcjonariusza, który ten środek egzekucyjny stosuje. Zgodnie $z$ art. 6 ust. 1 powyższej ustawy środków przymusu bezpośredniego używa się lub wykorzystuje się je w sposób niezbędny do osiagnnięcia celów tego użycia lub wykorzystania, proporcjonalnie do stopnia zagrożenia, wybierając środek o możliwie jak najmniejszej dolegliwości.

Należy podkreślić, że przepis art. 148 § 2 ustawy egzekucyjnej zawiera w sobie cztery przykłady sytuacji, w których można zastosować przymus bezpośredni. Pierwsza z nich dotyczy obowiązku wydania rzeczy czy też opuszczenia nieruchomości (lokalu). Najczęściej stosowanie przymusu w tym zakresie będzie miało charakter posiłkowego środka egzekucyjnego, jednak nie można wykluczyć zastosowania go z pominięciem przepisów art. 136 i 141 u.p.e.a. ${ }^{7}$ Zgodnie z orzeczeniem NSA: „w przypadku prowadzenia przez organ postępowania egzekucyjnego mającego na celu opróżnienie lokalu mieszkalnego, w przypadku nieopróżnienia lokalu jest to podstawowy środek egzekucyjny, który jest stosowany"8. Kolejna sytuacja dotyczy stosowania przymusu w przypadku, gdy egzekwuje się obowiązek polegający na zaniechaniu czegoś lub nieprzeszkadzaniu innej osobie w wykonywaniu jej praw. Wówczas przymus będzie miał charakter środka samoistnego,

6 Ustawa z dnia 24 maja 2013 r. o środkach przymusu bezpośredniego i broni palnej (Dz.U. z 2013 r., poz. 628 z późn. zm.).

7 R. Hauser, A. Skoczylas (red.), Postepowanie egzekucyjne w administracji. Komentarz, C.H. Beck, Warszawa 2014, s. 581.

8 Wyrok NSA z dnia 29 lutego 2012 r., sygn. akt I OSK 2112/11. Powyższe dotyczy sytuacji, w której po zastosowaniu środka egzekucyjnego polegającego na wydaniu nieruchomości albo opróżnieniu lokalu lub innych pomieszczeń zobowiązany nadal odmawia jej wydania. 
czyli stosowanego samodzielnie jako podstawowy środek egzekucyjny. Niemniej należy podkreślić, że w powyższym przypadku organ egzekucyjny prowadzący postępowanie będzie miał do dyspozycji prawdopodobnie również grzywnę w celu przymuszenia, bowiem przesłanki tych środków są podobne. Wówczas organ, kierując się zasadami ogólnymi postępowania egzekucyjnego, będzie zobowiązany wybrać środek jednocześnie najmniej uciążliwy dla zobowiązanego, a z drugiej strony skuteczny. Trzecia sytuacja dotyczy zaniechania czynności. Przesłanka ta jest również tożsama z przesłanką do nałożenia grzywny w celu przymuszenia i w tej sytuacji również od uznania organu będzie zależało zastosowanie konkretnego środka. Ostatnia sytuacja dotyczy przypadków, w których ze względu na charakter obowiązku stosowanie innych środków egzekucyjnych nie jest możliwe (art. 148 § 2 in fine u.p.e.a.). Sytuacje takie będą mieć miejsce głównie, gdy zwłoka w wykonaniu obowiązku zagraża zdrowiu, życiu bądź może uniemożliwić lub znacznie utrudnić dochodzenie wykonania obowiązku przez zobowiązanego (tzw. przymus natychmiastowy ${ }^{9}$ ). Będą to zarówno przypadki, gdy stosowanie innych środków egzekucyjnych jest niemożliwe z przyczyn faktycznych, jak i prawnych. Niemożliwość prawna stosowania innych środków egzekucyjnych ma miejsce wówczas, gdy przepis prawa nakazuje zastosowanie przymusu bezpośredniego jako jedynego środka prawnego $\mathrm{w}$ danej sytuacji ${ }^{10}$.

Należy podkreślić, że ustawa egzekucyjna w dwóch odrębnych przepisach reguluje przymus natychmiastowy ${ }^{11}$, upraszczając procedurę stosowania przymusu bezpośredniego. Pierwszym z nich jest art. $150 \S 3$ i 4 u.p.e.a., zgodnie z którym, jeżeli zwłoka w wykonaniu obowiązku może zagrozić zdrowiu lub życiu albo spowodować niemożność lub znaczne utrudnienie w dochodzeniu wykonania przez zobowiązanego obowiązku, a także w innych przypadkach określonych w odrębnych przepisach ${ }^{12}$, może być niezwłocznie zastosowany przymus bezpośredni wykonania obowiązku wynikajacego z przepisu prawa, po ustnym wezwaniu organu egzekucyjnego, bez uprzedniego upomnienia zobowiązanego oraz bez doręczenia mu odpisu tytułu wykonawczego i postanowienia o wezwaniu do wykonania obowiązku. Należy podkreślić, że do korzystania z powyższego przepisu są uprawnione wszystkie organy egzekucyjne egzekwujące obowiązki

\footnotetext{
R. Hauser, A. Skoczylas (red.), op. cit., s. 582.

J. Radwanowicz, op. cit., s. 489.

11 J. Jendrośka, Zagadnienia prawne wykonania aktu administracyjnego, Prace Wrocławskiego Towarzystwa Naukowego, seria A, nr 87, Wrocław 1963, s. 93-94.

12 Dla przykładu zgodnie z art. 31a ust. 9 ustawy z dnia 21 listopada 1967 r. o powszechnym obowiązku obrony Rzeczypospolitej Polskiej (Dz.U. z 2016 r., poz. 1534 z późn. zm.). Także w art. 61 ust. 2 ustawy obronnej wskazano tożsamy środek egzekucyjny.
} 
o charakterze niepieniężnym, a także na podstawie art. $150 \S 4$ u.p.e.a. organ celny przy sprawowaniu kontroli celnej ${ }^{13}$. Co istotne, przymus natychmiastowy może być stosowany na podstawie art. $150 \S 3$ ustawy egzekucyjnej tylko w przypadku, gdy dotyczy egzekwowania obowiązków wynikających bezpośrednio z przepisów prawa ${ }^{14}$. Tym samym nie ma możliwości stosowania go w celu realizacji obowiązków pochodzących z aktów indywidualnych.

Odnosząc się do zagadnienia obowiązku powstającego z mocy prawa, należy wskazać, że obowiązek ten powstaje w sytuacji, gdy zaistnieje stan faktyczny, $\mathrm{z}$ którym norma prawna wyrażona w przepisach wiąże określone konsekwencje prawne. Brak jego wykonania powoduje uruchomienie władczych środków, bez możliwości skorzystania przez zobowiązanego ze środków zaskarżenia przewidzianych w postępowaniu administracyjnym ${ }^{15}$. Przykładami obowiązków niepieniężnych powstających z mocy prawa są: obowiązek szczepień ${ }^{16}$, obowiązek szkolny ${ }^{17}$, obowiązek rocznego przygotowania przedszkolnego ${ }^{18}$, opłata dodatkowa ${ }^{19}$ czy obowiązek udostępniania odpowiednim organom dokumentacji budowlanej, w tym dziennika budowy ${ }^{20}$. Należy wskazać, że zgodnie z wyrokiem NSA z dnia 6 kwietnia $2011 \mathrm{r}^{21}$ wydanie decyzji w sprawie, w której zgodnie $\mathrm{z}$ przepisami prawa nie podlega autorytatywnej konkretyzacji $\mathrm{w}$ tej formie prawnej, jest rażącym naruszeniem prawa, co stanowi podstawę stwierdzenia nieważności na podstawie art. $156 \S 1$ pkt 2 k.p.a. ${ }^{22}$

13 Należy podkreślić, że organowi celnemu przysługuje tylko możliwość stosowania natychmiastowego przymusu bezpośredniego. Z uwagi na fakt, że dyrektor izby celnej jest organem egzekucyjnym jedynie w zakresie egzekucji obowiązków o charakterze pieniężnym, powyższa kompetencja ma charakter wyjątkowy i jest możliwa do zastosowania jedynie w przypadku przeprowadzania kontroli celnych, podczas których zaistnieje przesłanka wskazana w art. $150 \S 3$ u.p.e.a.

14 Chodzi tu oczywiście o przepisy powszechnie obowiązujące.

15 Por. M. Karpiuk, Istota obowiązku wynikajacego bezpośrednio z przepisu prawa na przykładzie opłaty dodatkowej, Studia Iuridica Lublinensia 2011/16, s. 152 i n.

16 Artykuł 5 ust. 1 pkt 1 lit. b w związku z art. 17 ust. 1 ustawy z dnia 5 grudnia 2008 r. o zapobieganiu oraz zwalczaniu zakażeń oraz chorób zakaźnych u ludzi (Dz.U. z 2016 r., poz. 1866 z późn. zm.).

17 Art. 15 ustawy z dnia 7 września 1991 r. o systemie oświaty (Dz.U. z 2016 r., poz. 1943 z późn. zm.).

18 Art. 14 ust. 3 ustawy o systemie oświaty.

19 Art. 13 f w związku z art. 13 ust. 1 pkt 1 ustawy z dnia 21 marca 1985 r. o drogach publicznych (Dz.U. z 2016 r., poz. 1440 z późn. zm.).

20 Zob. art. 46 oraz art. 81c ustawy z dnia 7 lipca 1994 r. Prawo budowlane (Dz.U. z 2016 r., poz. 290 z późn. zm.).

${ }^{21}$ II OSK 32/11, Legalis.

22 Ustawa z dnia 14 czerwca 1960 r. Kodeks postępowania administracyjnego (Dz.U. z 2016 r., poz. 23 z późn. zm.). 
Drugim przepisem, który reguluje inną uproszczoną procedurę stosowania przymusu bezpośredniego jest art. 117 u.p.e.a., zgodnie z którym organy określone w art. $20 \S 2$ ustawy, w granicach swojej właściwości do nakładania obowiązków o charakterze niepieniężnym, mogą stosować środki egzekucyjne wskazane $\mathrm{w}$ art. 1a pkt 12 lit. b tiret drugie, trzecie i piąte również w celu wyegzekwowania wydanych bezpośrednio ustnych poleceń, bez potrzeby wystawienia tytułu wykonawczego i doręczenia zobowiązanemu postanowienia o zastosowaniu środka egzekucyjnego, jeżeli zwłoka w wykonaniu obowiązku groziłaby niebezpieczeństwem dla życia lub zdrowia ludzkiego albo ciężkimi szkodami dla gospodarstwa narodowego lub jeżeli wymaga tego szczególny interes społeczny. Zgodnie z powyższym przepisem uprawnione do stosowania przymusu bezpośredniego są tylko: każdy organ Policji, Agencji Bezpieczeństwa Wewnętrznego, Agencji Wywiadu lub Straży Granicznej, Generalny Inspektor Ochrony Danych Osobowych, organ Państwowej Inspekcji Pracy wydający decyzję w pierwszej instancji, organ straży pożarnej kierujący akcją ratowniczą, a także inne organy powołane do ochrony spokoju, bezpieczeństwa, porządku, zdrowia publicznego lub mienia społecznego (art. $20 \S 2$ u.p.e.a.). Powyższe organy w zakresie swojej właściwości do nakładania obowiązków o charakterze niepieniężnym są uprawnione do stosowania odmiennie niż na podstawie art. 117 aż trzech środków egzekucyjnych, tj. wykonania zastępczego, odebrania rzeczy ruchomej oraz przymusu bezpośredniego.

Wymienione środki egzekucyjne są stosowane w celu wyegzekwowania obowiązków wynikających bezpośrednio z mocy prawa oraz z aktu indywidualnego, choć przede wszystkim będą przymusowo realizować ustne polece$n^{2}{ }^{23}$. Również ten tryb uproszczony polega przede wszystkim na możliwości organów egzekucyjnych do stosowania środków egzekucyjnych z pominięciem procedury, tj. obowiązku wystawienia przez wierzyciela tytułu wykonawczego oraz doręczenia jego odpisu zobowiązanemu, a także doręczenia postanowienia o zastosowaniu środka egzekucyjnego. Należy podkreślić, że powyższy przepis w przeciwieństwie do art. $150 \S 3$ u.p.e.a. nie zwalnia wierzyciela z obowiązku realizacji zasady zagrożenia, czyli doręczenia zobowiązanemu pisemnego upomnienia, choć, jak wskazuje Z. Leoński, ,względy celowości przemawiają za tym, by uprzednio nie wystawiać pisemnego upomnienia ${ }^{24}$. Powyższe należy uznać za niekonsekwencję legislacyjną ustawodawcy, bowiem z uwagi na cel tej instytucji prawnej wymóg doręczenia upomnienia przez wierzyciela pozbawiałby

23 J. Radwanowicz, op. cit., s. 491.

24 R. Hauser, A. Skoczylas (red.), op. cit., s. 541. 
organy egzekucyjne możliwości natychmiastowego skorzystania ze środków egzekucyjnych, w tym z przymusu bezpośredniego na podstawie tego przepisu, pomimo zaistnienia odpowiednich przesłanek, m.in. wystapienia zagrożenia dla życia lub zdrowia ludzkiego. Należy podkreślić, że choć obowiązek ustnego wezwania przed zastosowaniem przymusu bezpośredniego na podstawie omawianego przepisu nie ciąży na organach egzekucyjnych/egzekutorach, to z uwagi na charakter tego środka egzekucyjnego celowe byłoby wezwanie zobowiązanego z zagrożeniem zastosowania tego środka. Na marginesie można zauważyć, że art. $150 \S 3$ u.p.e.a. przewiduje taki obowiązek po stronie organu egzekucyjnego.

\section{Procedura stosowania przymusu bezpośredniego w trybie zwykłym}

Przystępując do omawiania procedury zastosowania przymusu bezpośredniego, należy podkreślić, że organ egzekucyjny w zakresie egzekucji obowiązków o charakterze niepieniężnym jest związany wnioskiem wierzyciela $\mathrm{w}$ zakresie wskazanego środka egzekucyjnego. Obowiązek wskazania przez wierzyciela środka egzekucyjnego ciąży na nim na mocy art. 28 u.p.e.a. Jednak w przypadku, gdy inny środek w ocenie organu egzekucyjnego będzie mniej uciążliwy dla zobowiązanego oraz będzie prowadzić bezpośrednio do wykonania obowiązku, organ egzekucyjny będzie uprawniony do jego zmiany. Prowadząc rozważania dotyczące przymusu bezpośredniego, trudno wyobrazić sobie sytuację, choć nie można jej wykluczyć, w której omawiany środek egzekucyjny spełni powyższe przesłanki. O ile przymus bezpośredni z pewnością jest środkiem prowadzącym bezpośrednio do wykonania obowiązku, o tyle jego uciążliwość jest obiektywnie zbyt wysoka, aby uznać go za mniej uciążliwy od innych. Z drugiej strony, każdą sytuację organ egzekucyjny powinien ocenić indywidualnie, więc nie można jednoznacznie stwierdzić, że sytuacja taka nigdy nie będzie miała miejsca.

O zmianie środka egzekucyjnego organ egzekucyjny powinien zawiadomić wierzyciela niebędącego jednocześnie organem egzekucyjnym. Informacja ta powinna zostać przekazana $\mathrm{w}$ formie postanowienia, na które nie będzie przysługiwało zażalenie ${ }^{25}$, bowiem organ egzekucyjny zgodnie z art. $17 \S 1$ u.p.e.a. powinien zajmować stanowiska dotyczące postępowania egzekucyjnego w drodze postanowienia. Natomiast zgodnie z art. $141 \S 1$ k.p.a. na wydane w toku postępowania postanowienia przysługuje stronie zażalenie, gdy kodeks tak stanowi.

25 Powyższy pogląd podzielają W. Piątek, A. Skoczylas w komentarzu do art. 30 u.p.e.a., patrz: R. Hauser, A. Skoczylas (red.), op. cit., s. 209. 
Mając na uwadze odpowiednie stosowanie przepisów k.p.a. w postępowaniu egzekucyjnym, należy uznać, że na omawiane postanowienie zażalenie nie będzie przysługiwać. Co oczywiste, sytuacja dotycząca stosowanych środków egzekucyjnych ulega znaczącej zmianie, gdy organ egzekucyjny i wierzyciel sąjednym podmiotem. Wówczas organ egzekucyjny z urzędu zadecyduje o zastosowaniu odpowiedniego środka egzekucyjnego, wskazując go w tytule wykonawczym oraz wydając odpowiednie postanowienie w tym zakresie.

Egzekutor, wykonując wniosek wierzyciela bądź decydując się na zastosowanie przymusu bezpośredniego jako samoistnego środka egzekucyjnego ${ }^{26}$, powinien przed jego zastosowaniem doręczyć zobowiązanemu odpis tytułu wykonawczego oraz postanowienie organu egzekucyjnego o wezwaniu zobowiązanego do wykonania obowiązku pod rygorem zastosowania przymusu bezpośredniego. Taka sytuacja będzie miała miejsce, gdy powyższe czynności inicjują postępowanie egzekucyjne. Należy pamiętać, że z chwilą doręczenia odpisu tytułu wykonawczego zobowiązanemu zostaje wszczęta egzekucja, a po stronie zobowiązanego powstaje prawo skorzystania z zarzutu, jako podstawowego środka zaskarżenia w postępowaniu egzekucyjnym.

Jeżeli przymus bezpośredni jest stosowany jako kolejny środek egzekucyjny w postępowaniu, wówczas egzekutor doręcza jedynie postanowienie. Powyższe koresponduje z art. 32 u.p.e.a., który stanowi, że organ egzekucyjny lub egzekutor, przystępując do czynności egzekucyjnych, doręcza zobowiązanemu odpis tytułu wykonawczego, o ile nie został wcześniej doręczony. Warto zwrócić uwagę, że art. $150 \S 1$ u.p.e.a. stanowi lex specialis wobec art. 32 u.p.e.a., bowiem m.in. ogranicza on zakres podmiotów upoważnionych do doręczenia odpisu tytułu wykonawczego oraz postanowienia o wezwaniu do wykonania obowiązku, pod groźbą zastosowania przymusu bezpośredniego jedynie do egzekutora. Stosując wykładnię językowa, można dojść do wniosku, że nie jest możliwe w zakresie stosowania przymusu bezpośredniego doręczenie tych dokumentów przez organ

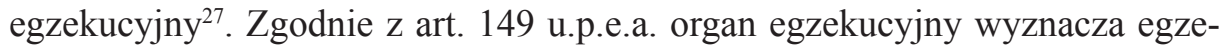
kutora w celu przeprowadzenia egzekucji przez zastosowanie przymusu bezpośredniego. Egzekutor jest pracownikiem organu egzekucyjnego umocowanym do dokonywania czynności egzekucyjnych. Artykuł 31 § 2 u.p.e.a. nakłada na niego obowiązek okazania zobowiązanemu bez wezwania przed rozpoczęciem czynności egzekucyjnych zaświadczenia organu egzekucyjnego lub legitymacji

26 Sytuacje takie zdarzają się dość rzadko.

27 Powyższa wykładnia prowadzi do sytuacji, w której podmiot posiadający kompetencję do upoważnienia egzekutora do pewnych czynności, sam nie może ich wykonywać. 
służbowej, upoważniających do czynności egzekucyjnych. Należy podkreślić, że czynnościami egzekucyjnymi są wszelkie podejmowane przez organ egzekucyjny działania zmierzające do zastosowania środka egzekucyjnego, w tym także doręczenie odpisu tytułu wykonawczego ${ }^{28}$.

Zobowiązany po otrzymaniu odpisu tytułu wykonawczego oraz omawianego postanowienia może skorzystać z przysługujących mu środków zaskarżenia. Zarzut przysługuje $\mathrm{w}$ terminie 7 dni od daty otrzymania przez zobowiązanego tytułu wykonawczego. Przesłanki stanowiące podstawę do wniesienia zarzutu zostały zawarte $w$ art. $33 \S 1$ u.p.e.a., który stanowi, że podstawą zarzutu w sprawie prowadzenia egzekucji administracyjnej może być: 1) wykonanie lub umorzenie w całości albo w części obowiązku, przedawnienie, wygaśnięcie albo nieistnienie obowiązku; 2) odroczenie terminu wykonania obowiązku albo brak wymagalności obowiązku z innego powodu, rozłożenie na raty spłaty należności pieniężnej; 3) określenie egzekwowanego obowiązku niezgodnie z treścią obowiązku wynikającego z orzeczenia; 4) błąd co do osoby zobowiązanego; 5) niewykonalność obowiązku o charakterze niepieniężnym; 6) niedopuszczalność egzekucji administracyjnej lub zastosowanego środka egzekucyjnego; 7) brak uprzedniego doręczenia zobowiązanemu upomnienia; 8) zastosowanie zbyt uciążliwego środka egzekucyjnego; 9) prowadzenie egzekucji przez niewłaściwy organ egzekucyjny; 10) niespełnienie przez tytuł wykonawczy wymogów określonych w art. 27, a w zagranicznym tytule wykonawczym - wymogów określonych w art. 102 ustawy o wzajemnej pomocy ${ }^{29}$. Co do zasady rozpatrzenie zarzutów następuje po uzyskaniu stanowiska wierzyciela ${ }^{30}$. Co więcej, w przypadkach zarzutów złożonych na podstawie art. $33 \S 1$ pkt 1-7, 9 i 10, a przy egzekucji

28 Warto zauważyć, że w doktrynie i orzecznictwie powstał spór dotyczący charakteru doręczenia odpisu tytułu wykonawczego. Obecnie nadal istnieją wątpliwości, czy jest to czynność egzekucyjna w rozumieniu art. 1a pkt 12 u.p.e.a. Por. wyrok NSA z 15 czerwca 1999 r., III SA 5420/98, ONSA 2000, Nr 4, poz. 145, pogląd przeciwny został wyrażony wyroku NSA z 14 stycznia 2005 r., FSK 1218/04, OSP 2005, Nr 12, poz. 142 czy wyroku WSA we Wrocławiu z 5 sierpnia 2008 r., I SA Wr 441/08, Legalis. Glosa krytyczna: J. Jankowski, M. Muliński, Glosa do wyroku Naczelnego Sadu Administracyjnego z 14.01.2005 r. (FSK 1218/04), Orzecznictwo Sądów Polskich 2005/12; Zob. też R. Hauser, A. Skoczylas (red.), op. cit., s. 21; Z. Kmiecik, Czynności egzekucyjne $w$ administracyjnym postęowaniu egzekucyjnym, w: J. Niczyporuk, S. Fundowicz, J. Radwanowicz (red.), op. cit., s. 237-247.

29 Ustawa z dnia 11 października 2013 r. o wzajemnej pomocy przy dochodzeniu podatków, należności celnych i innych należności pieniężnych (Dz.U. z 2013 r., poz. 1289 z późn. zm.).

30 Stanowisko wierzyciela nie jest wymagane jedynie w przypadku zarzutów zobowiązanego co do egzekucji z tytułów obcych przy dochodzeniu należności pieniężnych państwa członkowskiego UE oraz w egzekucji należności pieniężnych przekazanych do egzekucji administracyjnej na podstawie ratyfikowanych umów międzynarodowych. 
o charakterze niepieniężnym - także na podstawie art. $33 \S 1$ pkt 8, stanowisko wierzyciela jest dla organu egzekucyjnego wiążące. Stwierdzenie wystąpienia przesłanek niedopuszczalności postępowania o charakterze czasowym powoduje zawieszenie postępowania, natomiast uznanie przez organ, że w postępowaniu wystapiły przesłanki niedopuszczalności o charakterze trwałym, skutkować będzie umorzeniem tego postępowania. Jednak w przypadku, gdy zarzut został oparty na podstawie art. $33 \S 1$ pkt 8 u.p.e.a., organ egzekucyjny może zmienić środek egzekucyjny na mniej uciążliwy. Podkreślenia wymaga, że żaden z innych środków ochrony w tym postępowaniu nie wywiera bezpośrednio podobnych skutków $^{31}$. Prowadząc rozważania dotyczące przymusu bezpośredniego, szczególną uwagę warto zwrócić na podstawę zarzutu, jaką jest zastosowanie zbyt uciążliwego środka egzekucyjnego.

Zarzut będzie zasadny, gdy organ egzekucyjny zastosuje przymus z naruszeniem zasady stosowania środków egzekucyjnych najmniej uciążliwych dla zobowiązanego. Celem postępowania jest bowiem doprowadzenie do przymusowej realizacji jego obowiązków - nie zaś do wyrządzania mu dolegliwości. Jednak zaznaczenia wymaga, że o zastosowaniu najmniej uciążliwego środka egzekucyjnego można mówić wówczas, gdy istnieje w tej kwestii możliwość wyboru $^{32}$. Jeżeli natomiast w konkretnym przypadku organ egzekucyjny ma do dyspozycji tylko jeden środek egzekucyjny, to wówczas jest on nie tyle uprawniony, co zobowiązany do jego stosowania ${ }^{33}$. Rozpatrzenie zarzutów następuje po otrzymaniu ostatecznego postanowienia wierzyciela również w drodze postanowienia, na które przysługuje zażalenie. W sytuacji wykorzystania przez zobowiązanego środków obrony przed wadliwym postępowaniem i egzekucją na drodze administracyjnej, tj. wniesienia zarzutu oraz zaskarżenia postanowienia w sprawie jego rozpoznania, otwiera się możliwość dochodzenia swoich praw przed sądem administracyjnym ${ }^{34}$.

Inne środki prawne, takie jak zażalenie na postanowienie dotyczące przymusu bezpośredniego czy też skarga na czynności egzekucyjne, w odróżnieniu

31 Zob. L. Klat-Wertelecka, Ochrona jednostki przed wadliwa egzekucja administracyjna, w: J. Sługocki (red.), Dziesięć lat polskich doświadczeń w Unii Europejskiej: problemy prawnoadministracyjne, t. 2, PRESSCOM, Wrocław 2014, s. 627-640.

32 E. Komorowski, Zarzuty w egzekucji administracyjnej, w: J. Niczyporuk, S. Fundowicz, J. Radwanowicz (red.), op. cit., s. 521.

33 Wyrok NSA z dnia 9 lutego 2000 r., I SA/Gd 213/98, Lex 40392.

34 Szerzej: K. Sobieralski, Zagadnienia sadowej kontroli egzekucji administracyjnej, w: J. Niczyporuk, S. Fundowicz, J. Radwanowicz (red.), op. cit., s. 562-563; B. Adamiak, Skarga i skarga kasacyjna $w$ postępowaniu sądowoadministracyjnym. Komentarz, Wolters Kluwer, Warszawa 2014. 
od zarzutów, służą jedynie zagwarantowaniu praw określonym podmiotom postępowania, a ich uruchomienie umożliwia zbadanie, czy postępowanie jest prowadzone zgodnie z prawem ${ }^{35}$. Skarga na czynności egzekucyjne będzie przysługiwała zobowiązanemu tylko $\mathrm{w}$ wypadku, gdy nie przysługuje mu inny środek zaskarżenia, przede wszystkim zarzut. Zgodnie z wyrokiem z dnia 14 marca 1997 r. „dopuszczalność wniesienia skargi z art. 54 § 1 u.p.e.a. na czynności egzekucyjne organu egzekucyjnego lub egzekutora ograniczona jest w czasie nie zwykłym terminem liczonym w jednostkach czasowych, lecz stanem czynności egzekucyjnych w sprawie. Wyegzekwowanie obowiązku czyni skargę spóźnioną, ponieważ nawet jej merytoryczna zasadność nie może prowadzić do odwrócenia ostatecznego efektu postępowania egzekucyjnego w postaci przymusowego wyegzekwowania obowiązku"36.

W tym miejscu warto rozważyć, czy przysługujące zobowiązanemu środki zaskarżenia, w odniesieniu do przesłanek stosowania przymusu bezpośredniego gwarantują mu odpowiednią ochronę.

Biorąc pod uwagę katalog przysługujących zobowiązanemu środków zaskarżenia, przede wszystkim zarzut czy skargę na czynności egzekucyjne, należy stwierdzić, że dysponuje on odpowiednimi narzędziami do ochrony swoich praw w toku postępowania egzekucyjnego. Jednak charakter faktyczny i prawny przymusu bezpośredniego powoduje, że najczęściej będą to środki zaskarżenia przysługujące zobowiązanemu dopiero po przeprowadzonych czynnościach egzekucyjnych. Tym samym zobowiązany de facto nie ma możliwości uniknięcia przeprowadzenia tego środka egzekucyjnego, chyba że na mocy art. $45 \S 1$ u.p.e.a. wykaże, że obowiązek będący przedmiotem egzekucji został wykonany, umorzony, wygasł, nie istnieje lub jego wykonanie zostało odroczone w czasie, a także gdy zachodzi błąd co do osoby zobowiązanego. Wówczas organ egzekucyjny/ egzekutor ma obowiązek odstąpienia od czynności egzekucyjnych i zawiadomienia o tym fakcie wierzyciela.

Niezwykle istotną rolę w zakresie stosowania przymusu bezpośredniego przez organ egzekucyjny stanowią organy pomocnicze $i$ asystujące. Na podstawie art. $46 \S 1$ u.p.e.a. organ egzekucyjny i egzekutor może w razie potrzeby wezwać,

35 Zob. R. Hauser, Ochrona obywatela $w$ postępowaniu egzekucyjnym $w$ administracji, Wydawnictwo Naukowe Uniwersytetu im. Adama Mickiewicza w Poznaniu, Poznań 1988, s. 64; R. Hauser, Zarzut $w$ postępowaniu egzekucyjnym $w$ administracji, w: Z. Janku i in. (red.), $Z$ problematyki prawa administracyjnego i nauki administracji. Księga pamiątkowa $z$ okazji siedemdziesięciolecia urodzin Profesora Zbigniewa Leońskiego, t. 5, TERRA, Poznań 1999, s. $123-131$.

36 Wyrok WSA w Gdańsku z dnia 14 marca 1997 r., I SA/Gd 166/96, niepubl. 
w pilnych przypadkach, także ustnie, pomocy organu Policji, Straży Granicznej, Agencji Bezpieczeństwa Wewnętrznego lub Agencji Wywiadu, jeżeli natrafił na opór, który uniemożliwia lub utrudnia przeprowadzenie egzekucji, albo jeżeli istnieje uzasadnione przypuszczenie, że na taki opór natrafi. Jeżeli opór stawia żołnierz w czynnej służbie wojskowej, należy wezwać pomocy właściwego organu wojskowego, chyba że zwłoka grozi udaremnieniem egzekucji, a na miejscu nie ma organu wojskowego. Ponadto zgodnie z art. $45 \S 2$ u.p.e.a. powyższe organy nie mogą odmówić udzielenia pomocy egzekutorowi. Niewątpliwie organem, który najczęściej udziela pomocy lub asysty jest Policja. Organy Straży Granicznej czynią to w przypadkach, gdy przedmiot egzekucji znajduje się na terenie przejścia granicznego lub w strefie nadgranicznej. Jeżeli opór stawia żołnierz w czynnej służbie wojskowej, egzekutor powinien wezwać odpowiedni organ wojskowy, tj. Żandarmerię Wojskową, chyba że spowodowałoby to zwłokę grożącą udaremnieniem egzekucji, a na miejscu brak organu wojskowego. W celu doprecyzowania przepisów egzekucyjnych dotyczących udzielenia pomocy lub asysty, na podstawie delegacji ustawowej zawartej w art. $46 \S 3$ zostały wydane dwa akty wykonawcze. Pierwszym z nich jest rozporządzenie Ministra Spraw Wewnętrznych i Administracji w sprawie sposobu udzielania przez Policję lub Straż Graniczną pomocy lub asysty organowi egzekucyjnemu i egzekutorowi przy wykonywaniu czynności egzekucyjnych ${ }^{37}$, natomiast drugim jest rozporządzenie Ministra Obrony Narodowej w sprawie udzielania pomocy przez Żandarmerię Wojskową lub wojskowe organy porządkowe przy wykonywaniu czynności egzekucyjnych $\mathrm{w}$ administracji ${ }^{38}$.

Zgodnie z przepisami regulującymi pomoc lub asystę udzielaną przez Policję lub Straż Graniczną, czynności te polegają na umożliwieniu przeprowadzenia czynności egzekucyjnych, w szczególności poprzez zapewnienie dostępu do miejsca, w którym mają one być wykonywane; porządku w miejscu przeprowadzenia egzekucji administracyjnej; osobistego bezpieczeństwa organowi egzekucyjnemu i egzekutorowi, a w razie potrzeby - na uzasadnione żądanie organu egzekucyjnego i egzekutora - niezbędnej pomocy w zastosowaniu środków egzekucji administracyjnej. Natomiast pomoc Żandarmerii Wojskowej ograniczona została

37 Rozporządzenie Ministra Spraw Wewnętrznych i Administracji z dnia 29 sierpnia 2001 r. w sprawie sposobu udzielania przez Policję lub Straż Graniczną pomocy lub asysty organowi egzekucyjnemu i egzekutorowi przy wykonywaniu czynności egzekucyjnych (Dz.U., nr 101, poz. 1106).

38 Rozporządzenie Ministra Obrony Narodowej z dnia 5 lutego 2009 r. w sprawie udzielania pomocy przez Żandarmerię Wojskową lub wojskowe organy porządkowe przy wykonywaniu czynności egzekucyjnych w administracji (Dz.U., nr 31, poz. 212). 
jedynie do zapewnienia osobistego bezpieczeństwa organowi egzekucyjnemu $\mathrm{i}$ innym uczestnikom postępowania oraz zapewnieniu porządku w miejscu przeprowadzania egzekucji. Warto zaznaczyć, że powyższe przepisy budzą bardzo wiele problemów w praktyce. Organy prowadzące postępowania natrafiają na opór Policji w zakresie wykonywania przez nich obowiązku udzielania pomocy oraz asysty. W zasadzie rola Policji podczas czynności egzekucyjnych bardzo często jest ograniczona do fizycznego uczestnictwa funkcjonariuszy Policji podczas ich przeprowadzania oraz zapewniania bezpieczeństwa egzekutorowi i innym uczestnikom.

Pomimo obowiązku zapewnienia dostępu do miejsca, w którym mają być przeprowadzane czynności egzekucyjne, Policja odmawia np. rozkręcenia zamków czy wyważenia drzwi, co bardzo często prowadzi do fiaska czynności egzekucyjnych $^{39}$. Pomimo w miarę jasnej sytuacji prawnej z odmową Policji spotyka się również polecenie zastosowania przymusu bezpośredniego polegającego na doprowadzeniu zobowiązanego na miejsce czynności egzekucyjnych, pomimo że mieści się w granicach stosowania przymusu bezpośredniego (siła fizyczna w postaci technik transportowych ${ }^{40}$ ). Możliwość uzyskania pomocy przy stosowaniu przez egzekutora jest bardzo ważna z uwagi na specyfikę tego środka egzekucyjnego. Przymus bezpośredni jest wyjątkowo dolegliwy dla zobowiązanego, a jego zastosowanie jest możliwe tylko przez wyszkolone i umocowane do tego organy. Należy wskazać, że w większości przypadków uczestnictwo omawianych organów będzie sprowadzało się jedynie do asysty, czyli biernej obecności odpowiednich funkcjonariuszy podczas przeprowadzanych czynności. Warto zaznaczyć, że często sama obecność umundurowanych funkcjonariuszy powoduje łagodniejsze zachowania zobowiązanych. Ustawa egzekucyjna rozgranicza zagadnienie pomocy oraz asysty przy wykonywaniu czynności egzekucyjnych. Zgodnie z art. 50 § 2 u.p.e.a. w obrębie budynków wojskowych i zajmowanych przez Policję, Agencję Bezpieczeństwa Wewnętrznego, Agencję Wywiadu, Służbę Kontrwywiadu Wojskowego, Służbę Wywiadu Wojskowego, Centralne Biuro Antykorupcyjne lub Straż Graniczną oraz na okrętach wojennych można dokonywać czynności egzekucyjnych tylko po uprzednim zawiadomieniu odpowiednio właściwego komendanta lub kierownika jednostki $\mathrm{i}$ w asyście wyznaczonego organu wojskowego lub organu Policji, Agencji Bezpieczeństwa Wewnętrznego, Agencji Wywiadu, Służby Kontrwywiadu Wojskowego, Służby Wywiadu

39 Przykładem takiej sytuacji może być obowiązek udostępnienia budynku do kontroli organowi nadzoru budowlanego na mocy przepisów ustawy z dnia 7 lipca 1994 r. Prawo budowlane.

40 Art. 12 ust. 1 pkt a ustawy o środkach przymusu bezpośredniego i broni palnej. 
Wojskowego, Centralnego Biura Antykorupcyjnego lub Straży Granicznejej. Asysta polega na obecności w miejscu prowadzenia czynności egzekucyjnych i gotowości do udzielenia pomocy.

Ostatnią, ale nie najmniej istotną kwestią wartą rozważenia jest ograniczenie stosowania przymusu bezpośredniego w stosunku do osób korzystających z przywilejów i immunitetów dyplomatycznych. Powyższe ograniczenie nie dotyczy jednak spraw, w których osoby te podlegają orzecznictwu polskich organów administracyjnych. Ponadto zgodnie z art. $14 \S 2$ u.p.e.a. przeciwko powyższym podmiotom, które podlegają orzecznictwu organów polskich w rezultacie zrzeczenia się ich przywileju lub immunitetu przez państwo wysyłające lub odpowiednią organizację międzynarodową, może być prowadzona egzekucja administracyjna tylko w przypadku wyraźnego zrzeczenia się przywileju lub immunitetu także w odniesieniu do egzekucji administracyjnej. Należy pamiętać, że o ile w powyższym przypadku egzekucja jest dopuszczalna, o tyle nadal nie można wobec osób korzystających z immunitetu dyplomatycznego korzystać z przymusu bezpośredniego. Powyższe ograniczenie wprowadza art. $46 \S 3$ in fine u.p.e.a., stanowiąc, że niedopuszczalna jest egzekucja z mienia przeznaczonego do użytku służbowego ani też stosowanie środków egzekucyjnych w stosunku do osoby zobowiązanego.

\section{Zakończenie}

Przymus bezpośredni jest specyficznym środkiem egzekucyjnym. Jako jedyny ze wszystkich wymienionych w ustawie pozwala na ingerencję bądź zagrożenie tą ingerencją w nietykalność zobowiązanego oraz innych osób, przez co jest uznawany za środek drastyczny i najbardziej uciążliwy. Z drugiej strony ciężko wyobrazić sobie egzekucję administracyjną bez możliwości jego stosowania. W wielu przypadkach brak możliwości użycia przymusu bezpośredniego, zarówno jako samoistnego, jak i pomocniczego środka egzekucyjnego, kończyłoby się udaremnieniem egzekucji. Choć organy prowadzące postępowania powinny za każdym razem rozważyć konieczność jego użycia, szukając alternatywnych metod doprowadzenia do wykonania obowiązku, to nie ma możliwości całkowitego wyeliminowania go z obrotu prawnego i społecznego.

${ }^{41}$ Przepisy wykonawcze dotyczące asysty organów wojskowych zostały zawarte w rozporządzeniu Ministra Obrony Narodowej z dnia 11 marca 2010 r. w sprawie asystowania przez Służbę Kontrwywiadu Wojskowego, Służbę Wywiadu Wojskowego, Żandarmerię Wojskową lub wojskowe organy porządkowe przy wykonywaniu czynności egzekucyjnych w administracji (Dz.U., nr 54, poz. 324). 
W artykule został omówiony charakter prawny i szczegółowa procedura stosowania przymusu bezpośredniego. Podjęta została również próba odpowiedzi na pytanie, czy przesłanki stosowania przymusu bezpośredniego zostały ustanowione w sposób uwzględniający ochronę zobowiązanego. Wskazano, że z prawnego punktu widzenia ochrona zobowiązanego jest bardzo szeroka, bowiem może on korzystać z kilku środków zaskarżenia, m.in. zarzutu, zażalenia na postanowienie czy skargi na czynności egzekucyjne, a także zainicjować ścieżkę postępowania cywilnego. Jednak z uwagi na realny charakter stosowania przymusu bezpośredniego, zobowiązany w momencie stosowania tego środka egzekucyjnego nie ma de facto możliwości uniknięcia egzekucji. Przysługuje mu więc co do zasady ochrona prawna ex post, czyli dopiero po dokonanych czynnościach egzekucyjnych, które z uwagi na swój fizyczny wymiar, bardzo często nie mogą zostać uchylone, nawet pomimo zasadności zgłoszonych środków zaskarżenia.

Odnosząc się do postawionego we wstępie pracy problemu skuteczności stosowania przymusu bezpośredniego, należy stwierdzić, że biorąc pod uwagę rozwiązania prawne, jest to środek egzekucyjny o wysokiej skuteczności, bowiem prowadzi bezpośrednio do wykonania obowiązku, w odróżnieniu do grzywny w celu przymuszenia, która choć ma podobny zakres zastosowania, to nie jest środkiem zaspokajającym. Jednak z uwagi na częste uzależnienie działań organu egzekucyjnego lub egzekutora od woli organów pomocniczych efektywność ta drastycznie spada. Odmowa zastosowania przymusu bezpośredniego w określonych sytuacjach przez uprawnione organy prowadzi do bezskuteczności prowadzonej egzekucji, pozostawiając $\mathrm{w}$ dyspozycji organu jedynie pozostałe środki egzekucyjne, najczęściej grzywnę w celu przymuszenia. Należy bowiem pamiętać, że wiele organów egzekucyjnych nie posiada w zakresie swoich kompetencji możliwości faktycznego stosowania przymusu bezpośredniego, tym samym egzekutorzy nie mogą samodzielnie realizować tego środka.

\section{Bibliografia}

\section{Akty prawne}

Ustawa z dnia 17 czerwca 1966 r. o postępowaniu egzekucyjnym w administracji (Dz.U. z 2016 r., poz. 599 z późn. zm.).

Ustawa z dnia 14 czerwca 1960 r. Kodeks postępowania administracyjnego (Dz.U. z 2016 r., poz. $23 \mathrm{z}$ późn. $\mathrm{zm}$.).

Ustawa z dnia 24 maja 2013 r. o środkach przymusu bezpośredniego i broni palnej (Dz.U. z 2013 r., poz. 628 z późn. zm.).

Ustawa z dnia 21 listopada 1967 r. o powszechnym obowiązku obrony Rzeczypospolitej Polskiej (Dz.U. z 2016 r., poz. 1534 z późn. zm.). 
Ustawa z dnia 11 października 2013 r. o wzajemnej pomocy przy dochodzeniu podatków, należności celnych i innych należności pieniężnych (Dz.U. z 2013 r., poz. 1289 z późn. zm.).

Ustawa z dnia 5 grudnia 2008 r. o zapobieganiu oraz zwalczaniu zakażeń oraz chorób zakaźnych u ludzi (Dz.U. z 2016 r., poz. 1866 z późn. zm.).

Ustawa z dnia 7 września 1991 r. o systemie oświaty (Dz.U. z 2016 r., poz. 1943 z późn. zm.).

Ustawa z dnia 21 marca 1985 r. o drogach publicznych (Dz.U. z 2016 r., poz. 1440 z późn. zm.).

Ustawa z dnia 7 lipca 1994 r. Prawo budowlane (Dz.U. z 2016 r., poz. 290 z późn. zm.).

Rozporządzenie Ministra Obrony Narodowej z dnia 11 marca 2010 r. w sprawie asystowania przez Służbę Kontrwywiadu Wojskowego, Służbę Wywiadu Wojskowego, Żandarmerię Wojskową lub wojskowe organy porządkowe przy wykonywaniu czynności egzekucyjnych w administracji (Dz.U., nr 54, poz. 324).

Rozporządzenie Ministra Obrony Narodowej z dnia 5 lutego 2009 r. w sprawie udzielania pomocy przez Żandarmerię Wojskową lub wojskowe organy porządkowe przy wykonywaniu czynności egzekucyjnych w administracji (Dz.U., nr 31, poz. 212).

Rozporządzenie Ministra Spraw Wewnętrznych i Administracji z dnia 29 sierpnia 2001 r. w sprawie sposobu udzielania przez Policję lub Straż Graniczną pomocy lub asysty organowi egzekucyjnemu i egzekutorowi przy wykonywaniu czynności egzekucyjnych (Dz.U., nr 101, poz. 1106).

\section{Opracowania}

Adamiak Barbara, Borkowski Janusz, Kodeks postępowania administracyjnego. Komentarz, C.H. Beck, Warszawa 2014.

Adamiak Barbara, Skarga i skarga kasacyjna w postepowaniu sądowoadministracyjnym. Komentarz, Wolters Kluwer, Warszawa 2014.

Hauser Roman, Ochrona obywatela w postępowaniu egzekucyjnym w administracji, Wydawnictwo Naukowe Uniwersytetu im. Adama Mickiewicza w Poznaniu, Poznań 1988.

Hauser Roman, Skoczylas Andrzej (red.), Postępowanie egzekucyjne w administracji. Komentarz, C.H. Beck, Warszawa 2014, s. 581.

Hauser Roman, Zarzut w postępowaniu egzekucyjnym $w$ administracji, w: Zbigniew Janku i in. (red.), Z problematyki prawa administracyjnego i nauki administracji. Ksiegga pamiatkowa z okazji siedemdziesięciolecia urodzin Profesora Zbigniewa Leońskiego, t. 5, TERRA, Poznań 1999.

Jankowski Janusz, Muliński Maciej, Glosa do wyroku Naczelnego Sadu Administracyjnego z 14.01.2005 r. (FSK 1218/04), Orzecznictwo Sądów Polskich 2005/12.

Jendrośka Jan, Zagadnienia prawne wykonania aktu administracyjnego, Prace Wrocławskiego Towarzystwa Naukowego, seria A, nr 87, Wrocław 1963.

Karpiuk Mariusz, Istota obowiązku wynikającego bezpośrednio z przepisu prawa na przyktadzie opłaty dodatkowej, Studia Iuridica Lublinensia 2011/16.

Klat-Wertelecka Lidia, Ochrona jednostki przed wadliwa egzekucja administracyjna, w: Janusz Sługocki (red.), Dziesięć lat polskich doświadczeń w Unii Europejskiej: problemy prawnoadministracyjne, t. 2, PRESSCOM, Wrocław 2014.

Ostojski Przemysław, Zastosowanie przymusu bezpośredniego w egzekucji administracyjnej obowiązków niepieniężnych w Polsce i Niemczech, Państwo i Prawo 2013/8.

Radwanowicz Joanna, Przymus bezpośredni w egzekucji administracyjnej, w: Janusz Niczyporuk, Sławomir Fundowicz, Joanna Radwanowicz (red.), System egzekucji administracyjnej, C.H. Beck, Warszawa 2004. 
Iga JAWORSKA

\section{USE OF DIRECT COERCION IN ADMINISTRATIVE ENFORCEMENT PROCEEDINGS}

\section{( Sum mary)}

Direct coercion is one of the enforcement measures relating to the execution of the duties of non-pecuniary used by the enforcement authority in administrative enforcement proceedings. Undoubtedly this is the most burdensome enforcement measure for the debtor, since it might interfere in his inviolability. On the other hand, it is the measure usually directly linking to fulfill the obligation by the debtor, and thus effective. The aim of this article is to examine the legal nature of this measure, indication of circumstances and mode of application of an enforcement measure and the difficulties that may be encountered enforcement authority with a view to its use.

Keywords: direct coercion; enforcement proceeding; executor; obligation 